\title{
A Mid-Decade Update on Amish Settlement Growth
}

Joseph F. Donnermeyer

Professor Emeritus

School of Environment and Natural Resources

The Ohio State University

Cory Anderson

Visiting Assistant Professor of Sociology and Geography

Department of Society \& Environment

Truman State University

\begin{abstract}
The rapid growth of the Amish population brings a concomitant growth of new settlements. This research note provides a mid-century report on new Amish settlement growth in North America, emphasizing that the vast percentage of today's extant settlements have been established in the very recent past. As settlements in-fill around decades-old settlements, spatially distinctive Amish regions are taking shape, both in states of historic settlement and neighboring states. The apparent recent success of geographically outlying settlements is also of note, given the unequivocal failure of such settlements in the more distant past.
\end{abstract}

\section{Keywords}

Amish density; Amish regions; Amish demography; Amish population growth; GIS mapping; Heritage Historical Library, Aylmer, ON; Family Life

\section{Acknowledgements}

We gratefully acknowledge the Heritage Historical Library in Aylmer, ON, for making many valuable resources available that supported this ongoing research. 


\section{Introduction}

Previous issues of the Journal of Amish and Plain Anabaptist Studies (JAPAS) included articles pertaining to the demographic and geographic dimensions of the Amish (e.g., Donnermeyer, Anderson, and Cooksey 2013; Cooksey and Donnermeyer 2013; Donnermeyer and Luthy 2013; Donnermeyer and Anderson 2014; Donnermeyer 2015). Continuing this focus, the present research note offers a mid-decade update of settlement growth and dispersion. This update includes only those Amish within the (broadly-defined) Old Order camp, excluding the automobile-owning Amish-Mennonites, whose growth is slower.

Five years ago in the Mennonite Quarterly Review, Donnermeyer and Cooksey (2010) published an account of Amish settlement growth since 1990. In Table 1, they presented an historical overview of Amish settlements from 1800 to 2010. At the end of the twentieth century — namely, 1999 - there were 297 settlements. By the end of the next decade, the number had increased to 411. However, these and other counts in this table are subject to continuous but small adjustments because several settlements that were active then have since become extinct. One notable example is the Plain City, Ohio, community, founded in 1896 and located in central Ohio near the growing Columbus metropolitan area. It was considered extinct in 2011 (Luthy 2011) because a church service was no longer held there, even though a few older Amish still lived in the area (by van, they traveled to another settlement to attend church). Eventually, change makes all prior population statistics about the Amish - and for that matter, any other group of people-less useful for understanding the present.

\section{Data Collection}

What criteria are used to determine that an Amish settlement exists? Established by Luthy (2009) — and adopted by Donnermeyer and Cooksey (2010) in subsequent articles — to be counted as a settlement requires a minimum of three households (or two, if one household head is in the ministry) living in close proximity and able to hold a church service. In addition, "...the settlement must forbid ownership of motor vehicles and use the name "Amish"' (Luthy 2009, 2). This definition is both compatible with a sociological definition of community and consistent with Hostetler's (1993) description of an Amish community,

Information for this research note is identical to data collection procedures as described by Donnermeyer and Cooksey (2010) and Donnermeyer and Luthy (2013). In brief, using Luthy's (2009) definition of an Amish settlement, files made available from the Heritage Historical Library in Aylmer, Canada, and a scan of reports from The Diary, Die Botschaft, The Budget and other periodicals, evidence of new communities was established.

\section{Findings}

Given a doubling time estimate of 20.5 years for Amish population growth (Donnermeyer 2015), the number of Amish settlements likewise continues to grow. In their JAPAS article, Donnermeyer and Luthy (2013) listed 472 settlements, as of September 30, 2013 (the January 
Table 1: Amish Settlements by U.S. Census Regions, States, and Canadian Provinces

\begin{tabular}{|c|c|c|}
\hline Region/State & Total Extant & $\begin{array}{l}\text { New since } 1 / 1 / 10 \\
\text { (founded in } 2014 \text { or } 2015 \text { ) }\end{array}$ \\
\hline $\begin{array}{l}\text { New England } \\
\text { Maine } \\
\text { Vermont }\end{array}$ & $\begin{array}{r}5 \\
1 \\
\end{array}$ & $\begin{array}{l}2(0) \\
1(1)\end{array}$ \\
\hline Subtotal & $6(0.3 \%)$ & $3(1)$ \\
\hline $\begin{array}{c}\text { Middle Atlantic } \\
\text { New York } \\
\text { Pennsylvania }\end{array}$ & $\begin{array}{r}52 \\
57\end{array}$ & $\begin{array}{c}18(4) \\
5(1)\end{array}$ \\
\hline Subtotal & $109(21.8 \%)$ & $23(5)$ \\
\hline $\begin{array}{l}\text { East North Central } \\
\text { Illinois } \\
\text { Indiana } \\
\text { Michigan } \\
\text { Ohio } \\
\text { Wisconsin }\end{array}$ & $\begin{array}{l}18 \\
23 \\
42 \\
55 \\
50\end{array}$ & $\begin{array}{l}1(0) \\
2(0) \\
9(4) \\
6(2) \\
8(2)\end{array}$ \\
\hline Subtotal & $188(37.6 \%)$ & $26(8)$ \\
\hline $\begin{array}{l}\text { West North Central } \\
\text { Iowa } \\
\text { Kansas } \\
\text { Minnesota } \\
\text { Missouri } \\
\text { Nebraska } \\
\text { South Dakota }\end{array}$ & $\begin{array}{c}23 \\
7 \\
19 \\
41 \\
5 \\
1\end{array}$ & $\begin{array}{l}6(1) \\
0(0) \\
6(1) \\
7(2) \\
2(0) \\
1(0)\end{array}$ \\
\hline Subtotal & $96(19.2 \%)$ & $22(4)$ \\
\hline $\begin{array}{l}\text { South Atlantic } \\
\text { Delaware } \\
\text { Florida } \\
\text { Maryland } \\
\text { North Carolina } \\
\text { Virginia } \\
\text { West Virginia }\end{array}$ & $\begin{array}{l}1 \\
1 \\
3 \\
1 \\
6 \\
3\end{array}$ & $\begin{array}{l}0(0) \\
0(0) \\
0(0) \\
0(0) \\
2(0) \\
0(0)\end{array}$ \\
\hline Subtotal & $15(3.0 \%)$ & $2(0)$ \\
\hline $\begin{array}{l}\text { East South Central } \\
\text { Kentucky } \\
\text { Mississippi } \\
\text { Tennessee }\end{array}$ & $\begin{array}{c}41 \\
1 \\
9\end{array}$ & $\begin{array}{c}13(4) \\
0(0) \\
3(2)\end{array}$ \\
\hline Subtotal & $51(10.2 \%)$ & $16(6)$ \\
\hline $\begin{array}{l}\text { West South Central } \\
\text { Arkansas } \\
\text { Oklahoma } \\
\text { Texas }\end{array}$ & $\begin{array}{l}1 \\
4 \\
1\end{array}$ & $\begin{array}{l}0(0) \\
2(0) \\
0(0)\end{array}$ \\
\hline Subtotal & $6(1.2 \%)$ & $2(0)$ \\
\hline
\end{tabular}




\begin{tabular}{|l|c|c|}
\hline Region/State & Total Extant & $\begin{array}{l}\text { New since } 1 / 1 / 10 \\
\text { (founded in 2014 or 2015) }\end{array}$ \\
\hline $\begin{array}{l}\text { Mountain } \\
\text { Colorado }\end{array}$ & 4 & $1(0)$ \\
$\quad \begin{array}{c}\text { Idaho } \\
\text { Montana } \\
\text { Wyoming }\end{array}$ & 1 & $1(0)$ \\
1 & $1(1)$ \\
\hline Subtotal & $11(2.2 \%)$ & $4(1)$ \\
\hline $\begin{array}{l}\text { Canada } \\
\text { New Brunswick } \\
\text { Ontario }\end{array}$ & 1 & $1(1)$ \\
\hline Subtotal & 17 & $2(1)$ \\
\hline Grand Total & $18(3.6 \%)$ & $3(2)$ \\
\hline
\end{tabular}

2014 issue of Family Life carried a similar article, with a count of 473 settlements as of 10/31/13 (Luthy and Donnermeyer 2014)). Table 1 shows that the number of Amish communities is now - as of December 2015 - exactly 500. These settlements, both young and old, are present in 31 states and two Canadian provinces.

Table 1 organizes the states into U.S. Bureau of the Census regions. This same geographic arrangement was used in the Donnermeyer and Cooksey's (2010) article that focused on new Amish settlements founded since 1990. An Amish presence can be found in every region of the U.S.; however, most settlements remain confined to the Middle Atlantic states of New York and Pennsylvania, and various states of the East North Central and West North Central regions (i.e., the Midwest). Yet, there is a continued geographic spread of communities beyond these three census regions. New settlement growth has been most pronounced in states bordering historic regions of Amish settlement. The trend has been in-fill in regions now several decades proven. In a rigorous quantitative analysis of Amish settlement patterns, Anderson and Kenda (2015) found that settlement survival is related to proximity to existing Amish settlements, and very close settlement at that.

Of note, Kentucky now plays host to 41 Amish settlements, gaining 13 since January 1, 2010. Of these 13, four were founded in either 2014 or 2015. As well, there are now nine settlements in Tennessee. However, the most significant change in the geographic presence of the Amish in the U.S. is the rapid growth of settlements in the state of New York. Even though the oldest extant settlement in the Empire State - Conewango Valley in the southwestern county of Cattaraugus - started in $1948,{ }^{2}$ the Amish presence in New York came about mostly in the $21^{\text {st }}$ century. Of the 52 extant settlements in New York as of the writing for this article, 37 were founded since January 1, 2000. The number of extant settlements in New York now exceeds Wisconsin, and even though the pace of new settlements in the Empire States has moderated somewhat over the past several years, it would not be surprising if by 2020 it becomes the location of more Amish settlements than either Ohio or Pennsylvania. 


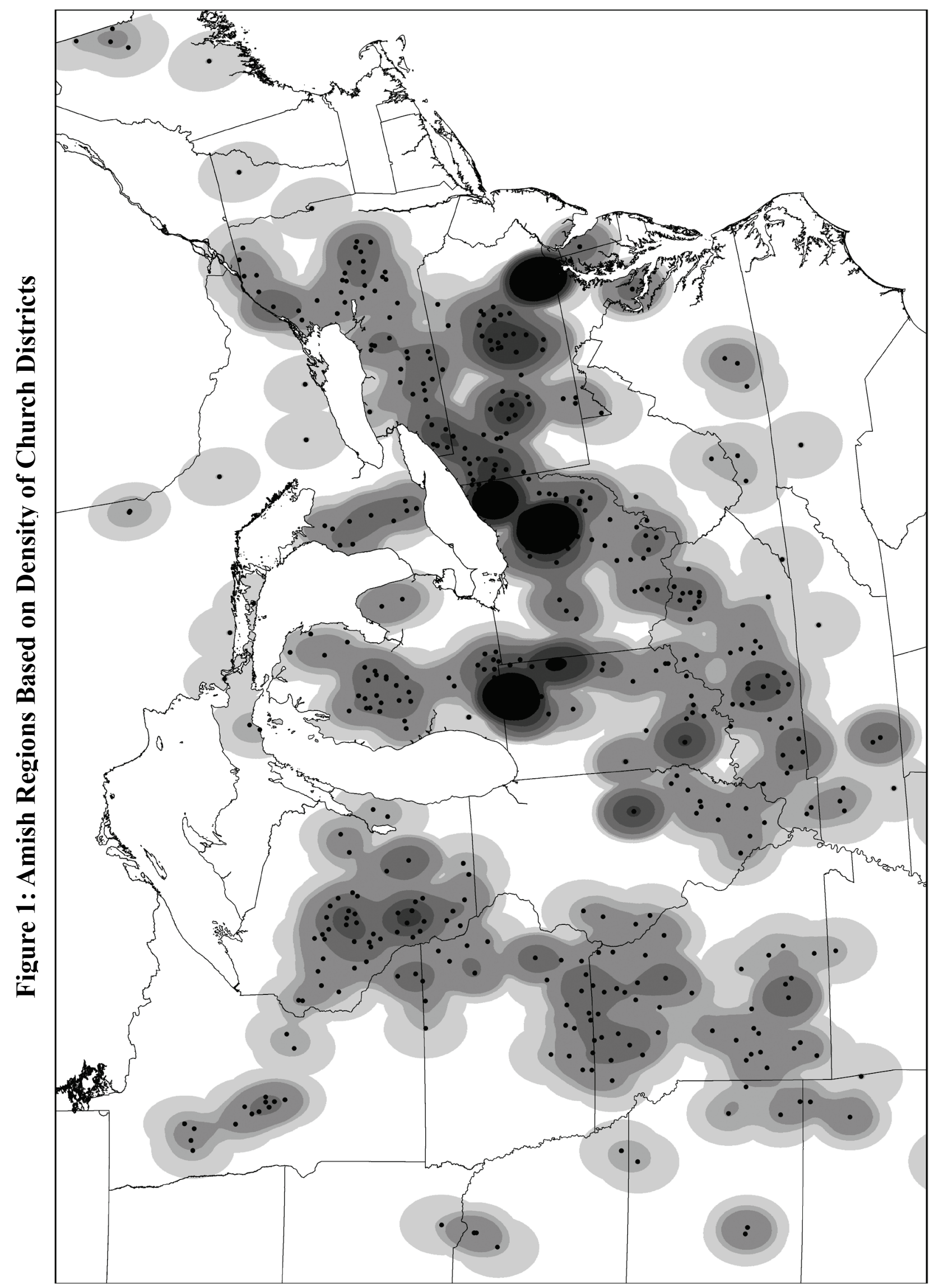


In Anderson and Donnermeyer (2013), we defined six categories of socio-spatial units of plain Anabaptist settlement. Some were more familiar (e.g. local church and settlement) than others (e.g. region and global region). With the phenomenal growth of Amish settlements in recent years, the geographical unit of "region" is much more apparent. Region was defined as, "Either a spatially apparent cluster of settlements within a distance that may be traversed regularly (such as for work) or a relative, subjective area concentrically weighted by the spatial and affiliative proximity of other community units from a given unit" (p. 5). Amish settlement patterns demonstrate both. Figure 1 is a density map of Amish settlements, weighted by the number of districts in each settlement. To generate this map, the kernel density spatial analysis tool in ArcGIS 10.3 was used, broken into eight increments of density. The map shows the extent to which Amish activity may be felt across North America.

In the central Midwestern states, four regions (spatially apparent clusters) are evident: (1) west central Minnesota; (2) central / western Wisconsin, southeastern Minnesota, and northeastern Iowa; (3) the Iowa-Missouri border and western Illinois; and (4) southern Missouri, southeastern Kansas, and northeastern Oklahoma. These regions lack a large nucleus settlement, but they are still more-or-less circular / radial. Such regions exist in more eastern locations as well: the northwestern portion of Michigan's Lower Peninsula; southern Ontario; and three in central / southeastern Pennsylvania, including the greater Lancaster County region itself.

Along the western foothills of the Appalachians, however, no region is as easily definable as among the aforementioned. Rather, settlements spread across a stretch that goes from northern New York to western Tennessee, disrupted by and large through the presence of metropolitan counties (Anderson and Kenda 2015; Donnermeyer and Anderson 2014). In this case, regions still exist, but are more subjective, realized more on a settlement-by-settlement basis as a certain distance to other settlements; settlements become less part of one's region as distance increases.

New settlements are also taking shape in peripheral areas, potential regions under development. Given the rapid growth of new Amish settlements, and the greater chances of survival when near another Amish settlement, these outer settlements may just take root, as the time it takes for a new settlement to start nearby is much shorter than in years past (Anderson and Kenda 2015). Recently established settlements in Vermont (2014) and New Brunswick (2015) mark two new entrants to the list of states / provinces in Table 1, although Luthy (2011) reports a short-lived Vermont settlement from the late 1970s. As well, Idaho, South Dakota, and Wyoming each contain only one Amish settlement, but were all founded since January 1, 2010.

Table 2 lists the chronological development of extant Amish communities. Significantly, nearly half of the 500 extant settlements did not exist before the beginning of the twenty-first century. Only 18 settlements founded before 1900 still exist today, and only another 16 begun during the first half of the twentieth century still exist. Of special note, no Amish settlement founded during the 1930s, the time of the Great Depression, still exists. Likewise, there was a dip in the number of extant Amish settlements founded in 2008 and 2009, the years that mark the height of the "Great Recession." 


\section{Table 2: Founding Date of Extant Amish Settlements}

\begin{tabular}{ccc}
$\begin{array}{c}\text { Settlement } \\
\text { Founded }\end{array}$ & $\begin{array}{c}\text { Number } \\
\text { (Percent) }\end{array}$ & Cumulative \\
\hline $1700 \mathrm{~s}$ or & & \\
$1800 \mathrm{~s}$ & $18(3.6 \%)$ & $3.6 \%$ \\
$1900-1909$ & $1(0.2 \%)$ & $3.8 \%$ \\
$1910-1919$ & $5(1.0 \%)$ & $4.8 \%$ \\
$1920-1929$ & $4(0.8 \%)$ & $5.6 \%$ \\
$1930-1939$ & $0(0.0 \%)$ & $5.6 \%$ \\
$1940-1949$ & $6(1.2 \%)$ & $6.8 \%$ \\
$1950-1959$ & $16(3.2 \%)$ & $10.0 \%$ \\
$1960-1969$ & $20(4.0 \%)$ & $14.0 \%$ \\
$1970-1979$ & $54(10.8 \%)$ & $24.8 \%$ \\
$1980-1989$ & $43(8.6 \%)$ & $33.4 \%$ \\
$1990-1999$ & $89(17.8 \%)$ & $51.2 \%$ \\
2000 & $15(3.0 \%)$ & $54.2 \%$ \\
2001 & $8(1.6 \%)$ & $55.8 \%$ \\
2002 & $18(3.6 \%)$ & $59.4 \%$ \\
2003 & $11(2.2 \%)$ & $61.6 \%$ \\
2004 & $12(2.4 \%)$ & $64.0 \%$ \\
2005 & $13(2.6 \%)$ & $66.6 \%$ \\
2006 & $23(4.6 \%)$ & $71.2 \%$ \\
2007 & $21(4.2 \%)$ & $75.4 \%$ \\
2008 & $12(2.4 \%)$ & $77.8 \%$ \\
2009 & $10(2.0 \%)$ & $79.8 \%$ \\
2010 & $20(4.0 \%)$ & $83.8 \%$ \\
2011 & $22(4.4 \%)$ & $88.2 \%$ \\
2012 & $16(3.2 \%)$ & $91.4 \%$ \\
2013 & $16(3.2 \%)$ & $94.6 \%$ \\
2014 & $13(2.6 \%)$ & $97.1 \%$ \\
2015 & $14(2.8 \%)$ & $100.0 \%$ \\
& &
\end{tabular}

\section{Conclusion}

On the horizon is the possibility of new Amish settlements in places far removed from their traditional home in the Middle Atlantic, North East Central, and North West Central regions of the U.S. and the Canadian province of Ontario. Based on reports from Amish periodicals and key informants, there are possibilities for new settlements in the eastern Canadian province of Prince Edward Island and in the South American countries of Argentina and Bolivia.

In the first issue of $J A P A S$, the article by Donnermeyer, Anderson, and Cooksey (2013) included projections for both population and settlement growth (see Table 9). It indicated that by the end of this decade, there would be 561 extant Amish communities. This mid-decade review of Amish settlement growth suggests that if this estimate is inaccurate to any extent, the reason will be because it is too low. 


\section{Endnotes}

${ }^{1}$ Contact information: Joseph Donnermeyer, School of Environment and Natural Resources, The Ohio State University, Columbus, Ohio 43210; donnermeyer.1@gmail.com; 614-582-4710.

${ }^{2}$ One extinct community_Croghan-lasted from 1830 to the end of the 1800s (Luthy 1986).

\section{References}

Anderson, Cory, and Joseph Donnermeyer. 2013. "Where Are the Plain Anabaptists?" Journal of Amish and Plain Anabaptist Studies 1(1):1-25.

Anderson, Cory, and Loren Kenda. 2015. "What Kinds of Places Attract and Sustain Amish Populations?" Rural Sociology 80(4):483-511.

Cooksey, Elizabeth, and Joseph Donnermeyer. 2013. "A Peculiar People Revisited: Demographic Foundations of the Iowa Amish in the $21^{\text {st }}$ Century." Journal of Amish and Plain Anabaptist Studies 1(1):110-26.

Donnermeyer, Joseph. 2015. "Doubling Time and Population Increase of the Amish." Journal of Amish and Plain Anabaptist Studies 3(1) 94-109.

Donnermeyer, Joseph, and Cory Anderson. 2014. "The Growth of Amish and Plain Anabaptist Communities in Kentucky." Journal of Amish and Plain Anabaptist Studies 2(2):215-44.

Donnermeyer, Joseph, and Elizabeth Cooksey. 2010. "On the Recent Growth of New Amish Settlements." Mennonite Quarterly Review 84(2):181-206.

Donnermeyer, Joseph, and David Luthy. 2013. "Amish Settlements across America: 2013." Journal of Amish and Plain Anabaptist Studies 1(2):107-29.

Donnermeyer, Joseph, Cory Anderson, and Elizabeth Cooksey. "The Amish Population: County Estimates and Settlement Patterns." Journal of Amish and Plain Anabaptist Studies 1(1):72-109.

Hostetler, John. 1993. Amish Society (4 ${ }^{\text {th }}$ ed.). Baltimore, MD: Johns Hopkins University Press.

Luthy, David. 1986. The Amish in America: Settlements That Failed, 1984-1960. Aylmer, ON: Pathway Publishers.

Luthy, David. 2009. Amish Settlements across America. Aylmer, ON: Pathway Publishers.

Luthy, David. 2011. Why Some Amish Communities Fail: Extinct Settlements, 1961-2011. Aylmer, ON: Pathway Publishers.

Luthy, David, and Joseph Donnermeyer. 2014. "Amish Settlements across America, as of October 31, 2013." Family Life (January):20-25. 


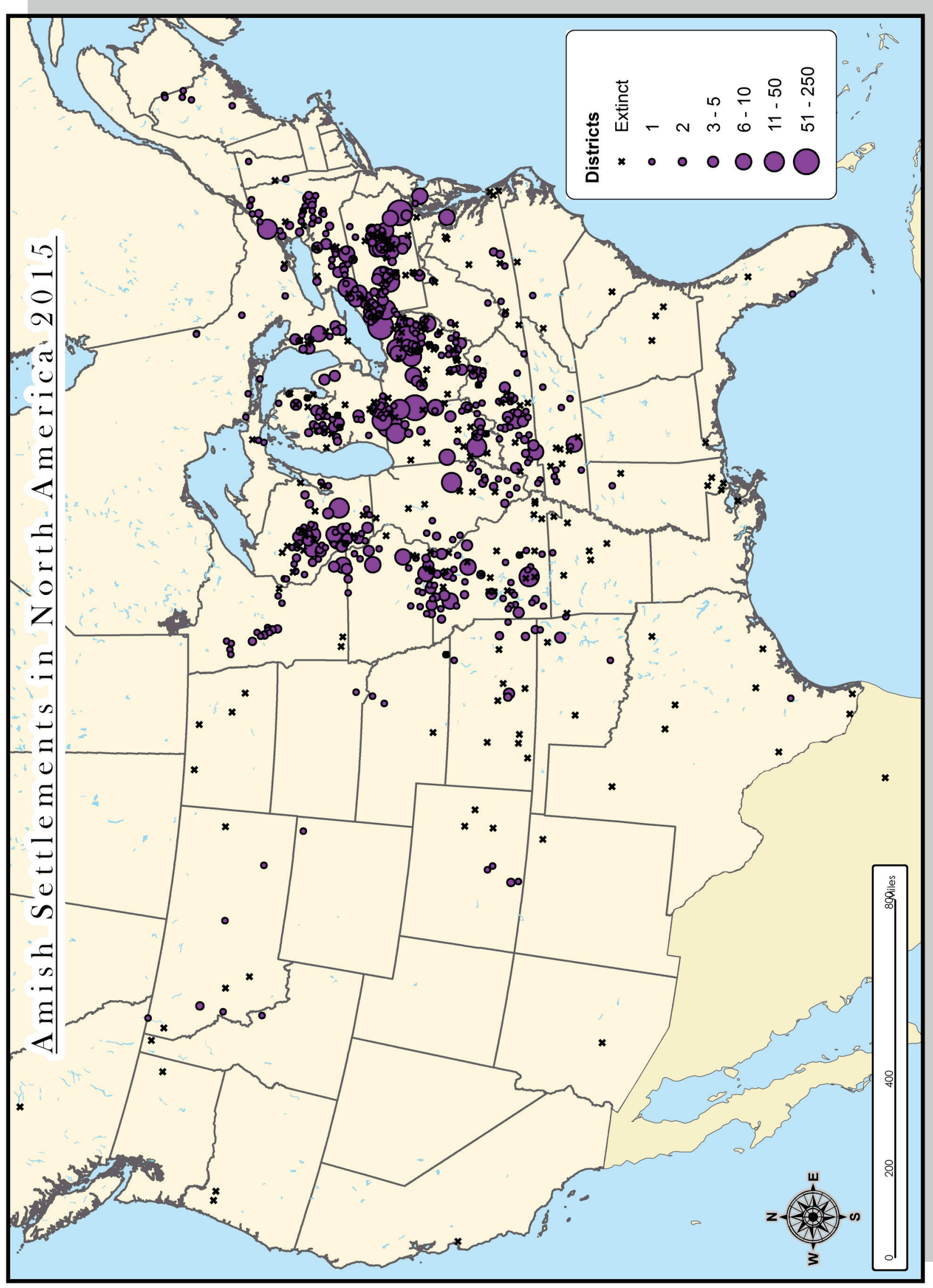




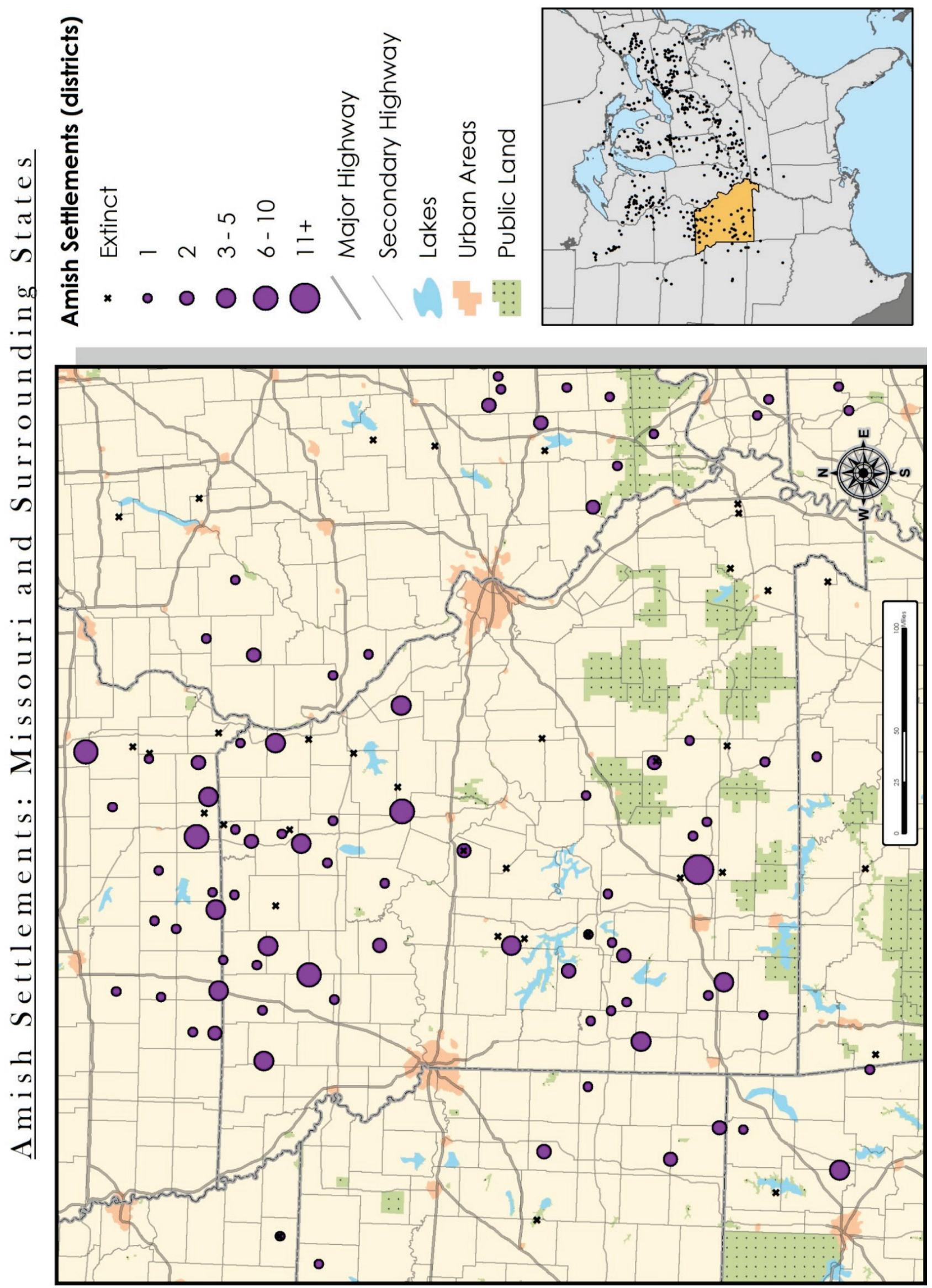




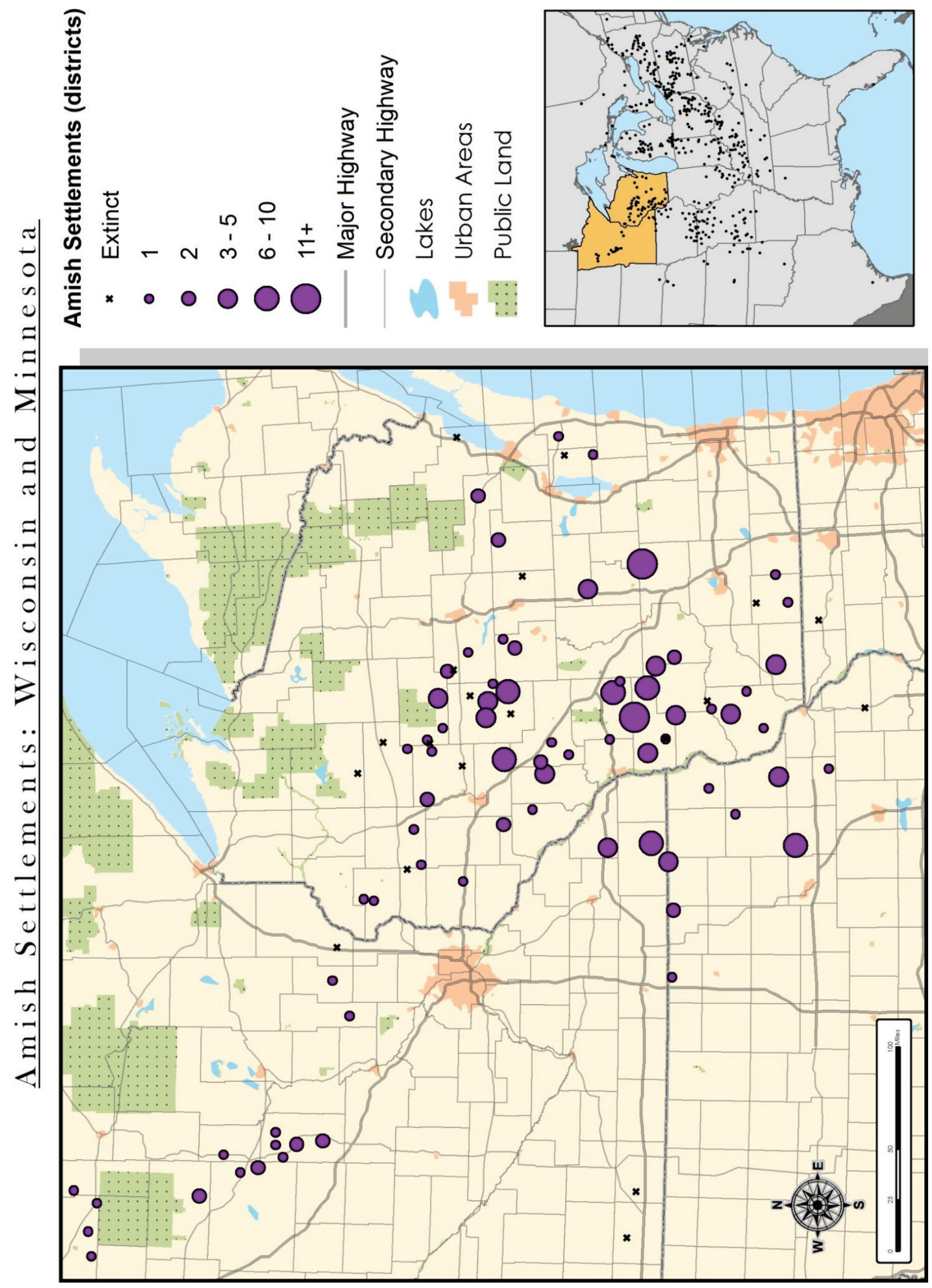




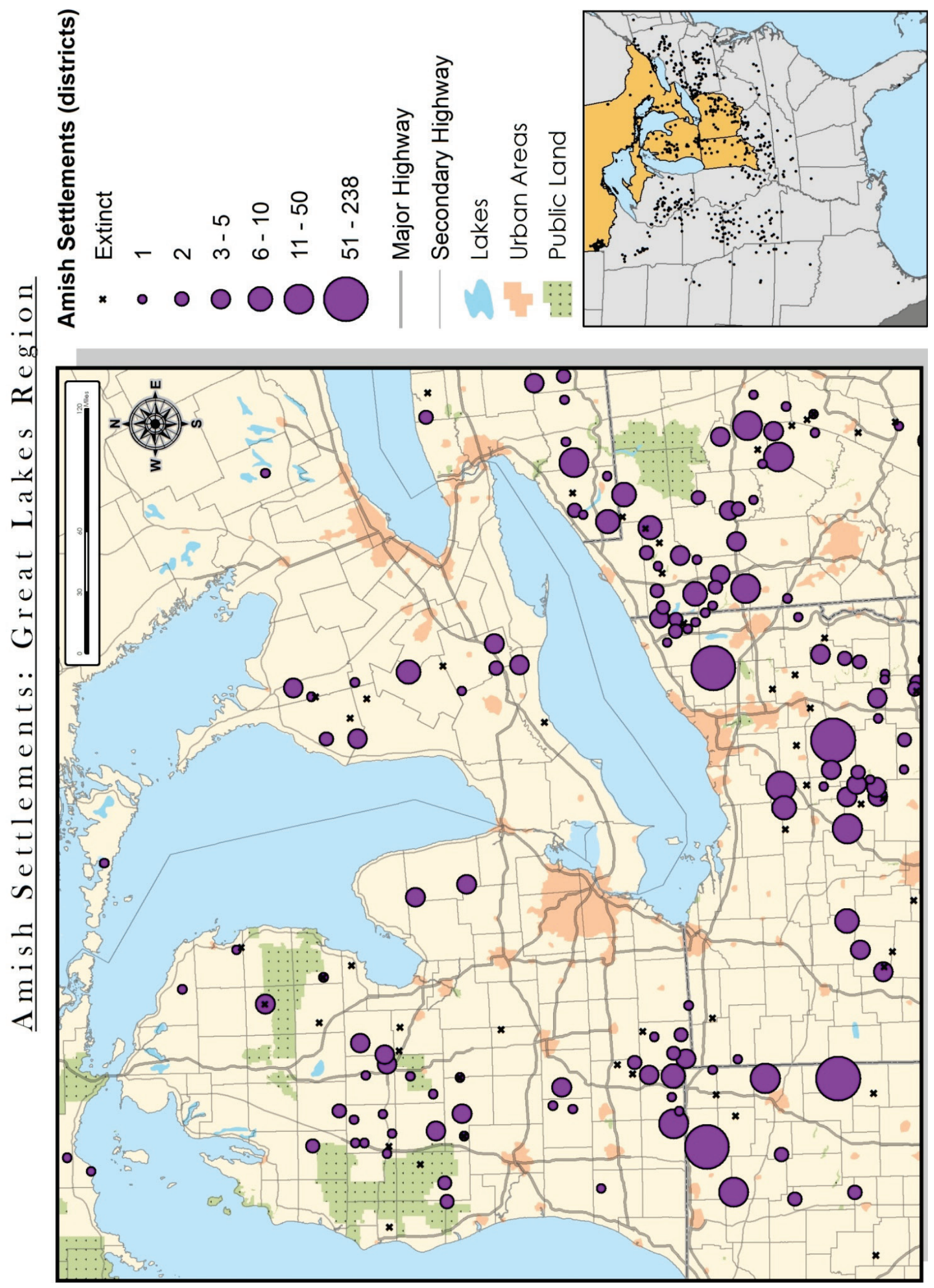




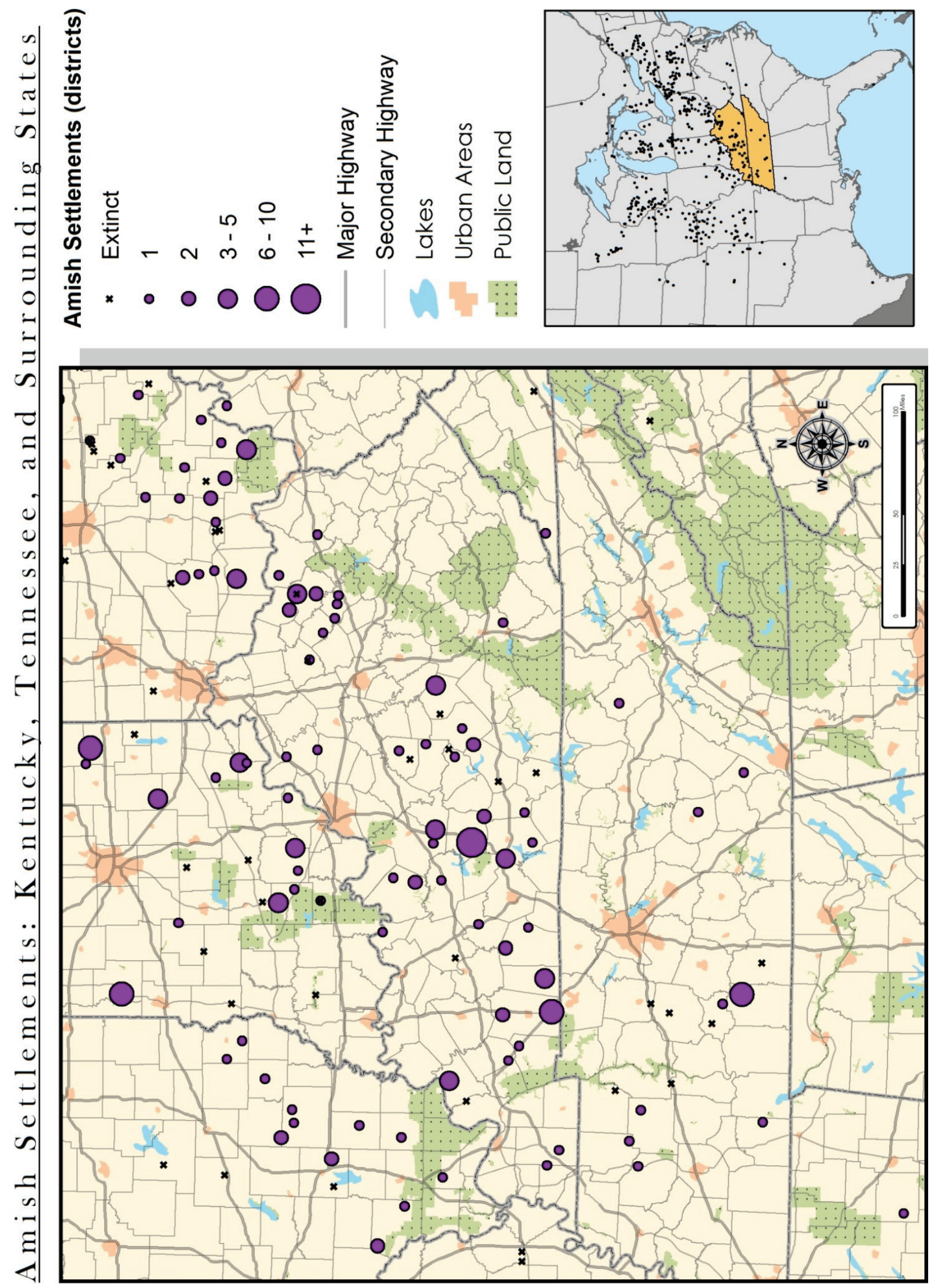




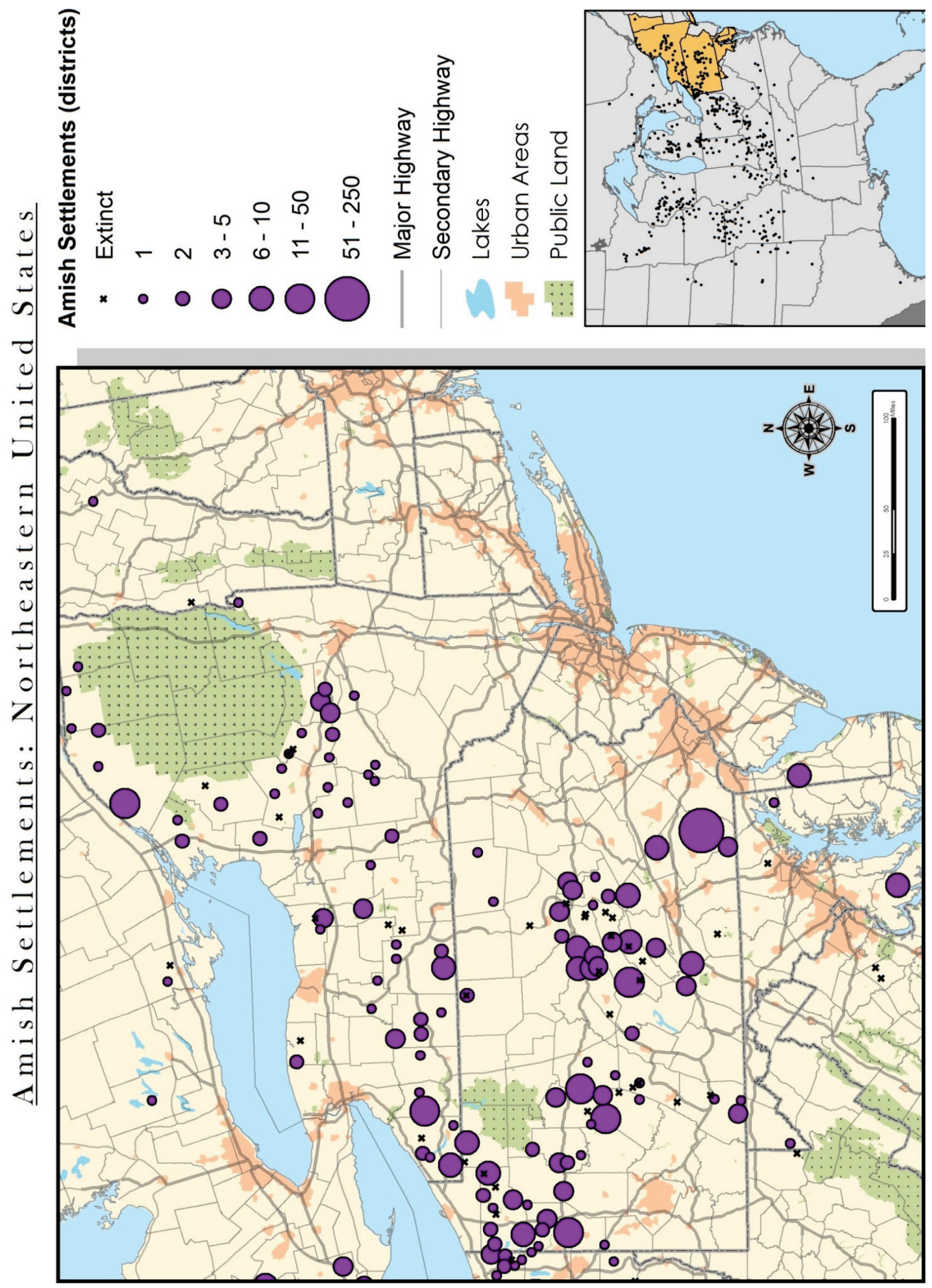

